\title{
PENGARUH LATIHAN NAFAS DALAM TERHADAP PENINGKATAN SATURASI OKSIGEN PADA KLIEN TERPASANG WATER SEAL DRAINAGE (WSD) DI RSUD KABUPATEN TANGERANG
}

\author{
*Yuningsih \\ *Akper Islamic Village Tangerang \\ Jl.Islamic Raya, Kelapa Dua - Tangerang 15810, Banten \\ Telp.021-5462852 \\ Email : yuningsih24@yahoo.com
}

\begin{abstract}
Abstrak
Di Indonesia kasus efusi pleura disebabkan oleh infeksi tuberkulosa. Tujuan umum penelitian ini terindentifikasi pengaruh nafas dalam terhadap saturasi oksigen pada klien terpasang WSD di RSU Kab.Tangerang. Penelitian ini merupakan penelitian pra eksperimen dengan rancangan penelitian yang digunakan pretest dan postest kelompok tunggal. Pada rancangan ini pengaruh efek atau treatmen diputuskan berdasarkan perbedaan antara pretest dan postest. Sampel yang digunakan sebanyak 20 orang. Menggunakan analisa data univariat dan bivariat. Hasil penelitian : Usia terbanyak pada responden dewasa pertengahan, klien bekerja, Jenis kelamin terbanyak: laki - laki, Pendidikan : SMA. Lamanya penyakit : 1- 3 bulan. Rata-rata saturasi oksigen sebelum dilakukan nafas dalam pada pagi hari: 96,65 sedangkan setelah dilakukan nafas dalam pada siang hari : 97,62 dengan $\mathrm{P}$ value : $0,000(\mathrm{P}<0,05)$ terdapat perbedaan yang signifikan saturasi oksigen antara sebelum dan setelah dilakukan nafas dalam. Variabel confounding tidak berpengaruh terhadap saturasi oksigen. Saran untuk perawat di ruang penyakit dalam : memberikan tindakan mandiri berupa nafas dalam agar ekspansi paru maksimal.
\end{abstract}

Kata kunci: Efusi pleura, nafas dalam, saturasi oksigen

\begin{abstract}
In Indonesia, cases of pleural effusion caused by tuberculosis infection. The general objective of this study: Identified influence of breath in the oxygen saturation in the client installed on the RSU Kab.Tangerang WSD. This research is a pre-experimental research design used pretest and posttest single group. In this design influence or effect of treatments was decided based on the difference between pretest and posttest. Samples used as many as 20 people. The analysis of the data that is univariate, bivariate analysis. RESULTS: Age largest at mid adult respondents, lient work, the highest Gender: Male - Male Education: high school. Disease duration: 13 months. The average oxygen saturation prior to breath in the morning: 96.65, while after a deep breath at noon: 97.62 with a $P$ value: 0.000 ( $P<0.05)$ there is a significant difference between the oxygen saturation before and after carried out a deep breath. Confounding variables did not affect the oxygen saturation. Suggestions for nurses in internal medicine: giving independent action in the form of breath in order to maximum lung expansion.
\end{abstract}

Keywords: pleural effusion, breathing, oxygen saturation. 


\section{PENDAHULUAN}

Badan Kesehatan Dunia (WHO) 2011 memperkirakan jumlah kasus efusi pleura di seluruh dunia cukup tinggi menduduki urutan ke tiga setelah $\mathrm{Ca}$ paru. Efusi pleura disebabkan oleh infeksi tuberkulosis. Efusi pleura adalah penumpukan cairan pada pleura (Sumantri, 2008). Terjadi apabila produksi meningkat minimal 30 kali normal atau adanya gangguan pada absorbsinya (Hariadi, 2010). Cairan pleura berupa eksudat, transudat dan chylus. Pada cairan pleura eksudat protein rasionya $>0,60$. Sedangkan chylus warnanya putih seperti susu dan mengandung lemak. Eksudat disebabkan oleh karena adanya kerusakan pada capillary bed di paru, pleura dan jaringan sekitarnya. Transudat disebabkan oleh tekanan hidrostatik yang meningkat atau tekanan osmotik yang menurun. Sedangkan pada absorbsi terhambat disebabkan adanya gangguan kemampuan kontraksi saluran lymphe, infiltrasi pada kelenjar getah bening dan kenaikan tekanan vena sentral tempat masuknya saluran lymphe. Adapun penatalaksanaan pada efusi pleura mencegah penumpukan kembali cairan, menghilangkan ketidaknyamanan serta dispnea. Jika torakosentesis tidak berhasil maka dilakukan Water Seal Drainage (WSD).

Berdasarkan hasil laporan dari ruang Cempaka RSUD Tangerang, pada bulan November dan Desember 2014, efusi pleura menduduki peringkat ke sembilan dari 10 penyakit terbanyak yang dirawat di ruang tersebut. Sedangkan jumlah klien yang terpasang WSD adalah 39 orang pada tahun 2014 di RSUD Kabupaten Tangerang merupakan rumah sakit tipe $B$, rumah sakit pendidikan yang berada di wilayah kabupaten Tangerang. Perawat di ruangan tersebut sudah melaksanakan perawatan WSD sesuai dengan teori seperti memberikan posisi, mempertahankan kepatenan sistem drainage, memantau drainage, dan water seal (segel air). Namun untuk perawatan yang mandiri seperti menganjurkan klien tarik nafas dalam belum dilakukan. Untuk pemeriksaan oksimetri tidak dilakukan, tetapi dilakukan pemeriksaan analisa gas darah apabila klien terasa sesak dan kondisi yang memburuk. Untuk itu peneliti tertarik untuk melakukan penelitian sejauh mana pengaruh nafas dalam terhadap saturasi oksigen pada klien terpasang WSD.

\section{METODE PENELITIAN}

Jenis penelitian ini menggunakan kuasi eksperimen dengan pendekatan pretest dan post test desain. Sampel yang digunakan dalam penelitian ini sebanyak 20 responden pada klien terpasang WSD di RSUD Kabupaten Tangerang.

\section{HASIL PENELITIAN}

Tabel 1.

Distribusi responden menurut karakteristik umur, jenis kelamin, pekerjaan, lamanya penyakit dan tingkat pendidikan di RSUD Kabupaten Tangerang tahun $2015(n=20)$

\begin{tabular}{llcc}
\hline No. & Variabel & Frekuensi & Persentase \\
\hline 1 & Umur : & & \\
& $18-39$ & 5 & 25.0 \\
& $40-59$ & 15 & 75.0 \\
\hline 2 & Status & & \\
& Pekerjaan & 17 & 85 \\
& Bekerja & 3 & 15 \\
& Tidak bekerja & & \\
\hline 3 & Jenis kelamin : & & \\
& Laki - laki & 16 & 80 \\
& Perempuan & 4 & 20 \\
\hline 4 & Pendidikan : & & \\
& SMP & 7 & 35 \\
& SMA & 13 & 65 \\
\hline 5 & Lamanya & & \\
& penyakit & 17 & 85 \\
& 1 - 3 bln & 3 & 15 \\
& $>3$ bln & & \\
\hline
\end{tabular}




\section{a. Umur}

Dari hasil analisis tabel 1. menunjukkan bahwa dari penelitian terhadap 20 orang responden di RSUD Kabupaten Tangerang, menunjukkan bahwa sebagian besar responden adalah dewasa pertengahan sebanyak $75 \%$.

\section{b. Status pekerjaan responden}

Dari hasil analisis tabel 1. menunjukkan bahwa dari penelitian terhadap 20 orang responden bahwa yang bekerja adalah $85 \%$.

\section{c. Jenis kelamin Responden}

Dari hasil analisis tabel 1. menunjukkan bahwa laki-laki sebanyak $80 \%$.

\section{d. Tingkat pendidikan}

Dari hasil analisis tabel 1. menunjukkan bahwa dari penelitian terhadap 20 orang responden bahwa yang lulus SMP $35 \%$ dan SMA $65 \%$.

\section{e. Lamanya penyakit}

Dari hasil analisis tabel 1. menunjukkan bahwa klien yang menderita efusi pleura selama $1-3$ bulan sebanyak $85 \%$ dan $4-6$ bulan sebanyak $15 \%$.

Tabel 2.

Mean, SD, Pengaruh Nafas Dalam terhadap Saturasi Oksigen

\begin{tabular}{lccc}
\hline Variabel & Mean & SD & P.Value \\
\hline $\begin{array}{l}\text { Saturasi O2 } \\
\text { sebelum dilakukan } \\
\text { nafas dalam }\end{array}$ & 96,65 & 1,001 & 0,000 \\
\hline $\begin{array}{l}\text { Saturasi O2 } \\
\text { setelah dilakukan } \\
\text { nafas dalam }\end{array}$ & 97,62 & 0,661 & \\
\hline
\end{tabular}

Rata-rata saturasi oksigen sebelum dilakukan nafas dalam : 96,65 sedangkan rata-rata saturasi oksigen setelah dilakukan nafas dalam adalah 97,62. Maka selisih rata-rata saturasi oksigen adalah 0,97 (SD : 0,34). Ada perbedaan saturasi oksigen setelah dilakukan nafas dalam.

Tabel 3.

Mean, SD, dan P value saturasi oksigen sebelum (Pre) dan setelah (Post) dilakukan nafas dalam menurut kelompok usia, jenis kelamin, tingkat pendidikan, pekerjaan dan lamanya penyakit

\begin{tabular}{|c|c|c|c|c|c|}
\hline NO & Keterangan & PRE/POS & MEAN & SD & P.VALUE \\
\hline \multirow[t]{6}{*}{1} & Usia $18-39$ & & & & \multirow{3}{*}{0,497} \\
\hline & Sat O2 & Pre & 97,4 & 0,566 & \\
\hline & Sat $\mathrm{O} 2$ & Pos & 97,8 & 0,283 & \\
\hline & Usia 40-59 & & & & \multirow{3}{*}{0.312} \\
\hline & Sat $\mathrm{O} 2$ & Pre & 96,4 & 1,000 & \\
\hline & Sat O2 & Pos & 97,56 & 0,745 & \\
\hline \multirow[t]{7}{*}{2} & Jenis Kelamin & & & & \multirow{6}{*}{0,452} \\
\hline & Laki & & & & \\
\hline & Sat $\mathrm{O} 2$ & Pre & 96,47 & 1,012 & \\
\hline & Sat O2 & Pos & 97,56 & 0,745 & \\
\hline & Perempuan & & & & \\
\hline & Sat $\mathrm{O} 2$ & Pre & 97,35 & 0,640 & \\
\hline & Sat $\mathrm{O} 2$ & Pos & 97,85 & 0,443 & 0,342 \\
\hline \multirow[t]{5}{*}{3} & Pendidikan & & & & \multirow{3}{*}{0,144} \\
\hline & SMP & Pre & 96,20 & 0,739 & \\
\hline & & Pos & 97,34 & 0,550 & \\
\hline & SMA & Pre & & & \\
\hline & & Pos & 97,77 & 0,687 & 0,151 \\
\hline \multirow[t]{5}{*}{4} & Lamanya Penyakit & & & & \multirow{3}{*}{0,329} \\
\hline & $1-3$ bulan & Pre & 96,73 & 0,980 & \\
\hline & & Pos & 97,68 & 0,641 & \\
\hline & $>3$ bulan & Pre & 96,20 & 1,217 & \multirow[t]{2}{*}{0,536} \\
\hline & & Pos & 97,68 & 0,641 & \\
\hline
\end{tabular}




\begin{tabular}{lllll}
\hline 5 & Pekerjaan & & & \\
Bekerja & Pre & 96,49 & 0,983 & 0,080 \\
& Pos & 97,56 & 0,683 & \\
& Pre & 97,53 & 0,643 & 0,098 \\
& Tidak Bekerja & 97,93 & 0,503 & \\
& Pos & \\
\hline
\end{tabular}

Tabel 3. menunjukkan tidak ada perbedaan dari kedua kelompok umur, jenis kelamin antara pria dan wanita, bekerja dengan tidak bekerja demikian pula antara kelompok pendidikan SMP dengan pendidikan SMA tidak ada perbedaan saturasi oksigen antara sebelum dan setelah dilakukan nafas dalam.

\section{PEMBAHASAN}

\section{Karakteristik responden}

\section{Usia}

Usia responden terbanyak yang menderita efusi pleura yaitu usia 40-60 tahun sebanyak $75 \%$. Usia termuda 27 tahun dan usia tertua 56 tahun. Pada kasus ini banyak terjadi pada usia pertengahan dewasa. Menurut pendapat (Alsagaf, 2010) kasus efusi pleura yang disebabkan oleh tuberkulosis lebih sering terjadi pada penderita berumur antara 21-30 tahun. Sedangkan menurut (Hiswari, 2009) penyakit efusi pleura yang disebabkan tuberkulosis paling sering ditemukan pada usia muda atau produktif 15-50 tahun. Usia merupakan faktor yang dapat menggambarkan kondisi dan mempengaruhi kesehatan seseorang. Semakin tua seseorang maka sistem tubuhnya terjadi penurunan fungsi sistem tubuh yang akan mempengaruhi daya fungsi tubuh.

\section{Jenis Kelamin}

Hasil penelitian ini menunjukkan jenis kelamin laki-laki sebesar $80 \%$ dan perempuan 20\%. Hal ini sesuai dengan pendapat (Alsagaff, 2010) penderita efusi pleura lebih sering terjadi pada laki-laki daripada wanita. Hal ini dikarenakan gaya hidup seperti sering merokok tembakau dan minum alkohol.
Sehingga dapat menurunkan sistem pertahanan tubuh, sehingga mudah terpapar dengan agent efusi pleura.

\section{Strata Pendidikan}

Hasil penelitian menunjukkan pendidikan SMP 35\% dan pendidikan SMA 65\%. Dari hasil tersebut penderita efusi pleura lebih banyak yang berpendidikan SMA. Yang memungkinkan mempunyai pengetahuan yang banyak tentang efusi pleura yang terpasang WSD. Sehingga bisa berbagi informasi dengan penderita yang lain. Menurut Notoatmojo (2010), pendidikan diperoleh dari jenjang pendidikan formal dan merupakan salah satu cara untuk mendapatkan pengetahuan. Semakin meningkat pengetahuan responden dan meningkat pula kemampuan untuk mengembangkan serta menjalani program terapi penyakitnya.

\section{Status Pekerjaan}

Hasil penelitian menunjukkan yang bekerja jumlahnya $85 \%$ dan yang tidak bekerja $15 \%$. Dengan demikian penderita efusi pleura yang terpasang WSD masih memiliki produktifitas untuk bekerja $85 \%$. Agar pengembangan paru maksimal sehingga klien masih bisa bekerja.

\section{Lamanya Penyakit}

Hasil penelitian menunjukkan lamanya menderita efusi pleura 1-3 bulan $85 \%$ sedangkan 4-6 bulan 15\%. Pada awalnya responden menderita tuberkulosa karena pengobatannya tidak tuntas sehingga terjadi efusi pleura. 


\section{KESIMPULAN}

\section{Kesimpulan}

1. Usia terbanyak pada klien efusi pleura yang terpasang WSD adalah usia dewasa pertengahan $75 \%$, jenis kelamin laki-laki sebanyak $85 \%$, pendidikan klien SMA sebanyak $65 \%$. Lamanya penyakit : $1-3$ bulan sebanyak $85 \%$ dan bekerja sebanyak $85 \%$.

2. Rata-rata saturasi sebelum dilakukan nafas dalam pada pagi hari : 96,86 dan setelah dilakukan nafas dalam pada siang hari : 97,67. Maka didapatkan Value : 0,00 ( $\mathrm{P}<$ 0,05) hasil uji statistik disimpulkan terdapat perbedaan saturasi.

3. Ada pengaruh yang signifikan terapi nafas dalam terhadap peningkatan saturasi oksigen.

\section{Saran}

1. Bagi institusi keperawatan

Bahwa nafas dalam dapat meningkatkan saturasi oksigen pada klien efusi pleura yang terpasang WSD. Oleh karena itu klien yang dipasang WSD dianjurkan untuk melakukan nafas dalam.

2. Bagi Institusi pendidikan

Mengembangkan dan memadukan teknik nafas dalam sebagai intervensi keperawatan ke dalam materi perkuliahan pada mata ajar keperawatan medikal bedah.

3. Bagi Peneliti selanjutnya

a. Hasil penelitian ini dapat dijadikan data dasar sekaligus bahan untuk melakukan penelitian lebih lanjut di lingkup sistem pernafasan.

b. Mengembangkan riset-riset terkait intervensi keperawatan untuk meningkatkan saturasi oksigen.

\section{DAFTAR PUSTAKA}

Balck \& Hawks. (2014). Keperawatan Medikal Bedah: Manajemen Klinis untuk Hasil yang Diharapkan. Philadelphia: Elsevier Sounders.

Baughman, Diane C,. (2000). Keperawatan Medikal Bedah: Buku Saku untuk Brunner dan Suddarth. alih bahasa oleh Yasmin Asih. Jakarta: EGC.

Benson, Herbert. MD., (2000). Respon Relaksasi: Teknik Meditasi Sederhana dan untuk Mengatasi Tekanan Hidup (terjemahan).Bandung: Mizan.

Brunner dan Suddarth, (2005). Keperawatan Medikal Bedah, Edisi 8, Vol. 2. Jakarta: EGC.

Bilo G, Revera M, Bussotti M. Bonacina D, Styczkiewicz K, et al. (2012). Effect of Slow Deep Breathing at High Altitude on Oxigen Saturation. Pulmonary and Systematic Hemodynamics.

Cerfolio et al. (2005). The Management of Chest Tubes in Patients With a Pneumothorax Kaushik, et.al. (2006). Effects of Mental Relaxation and Slow Breathing in Essential Hypertension. Complementary Therapies in Medecine. Vol 14(2). Pp. 120-126.

Dharma, K.K. (2011). Metodologi Penelitian Keperawatan (Pedoman Melaksanakan dan Menerapkan Hasil Penelitian). Jakarta: Trans Info Media, TIM.

Emaliyawati, Etika. (2009). Pengaruh Latihan Nafas Dalam terhadap Konsetrasi Oksigen Darah Diperifer pada Klien TBC Paru, (Pustaka.Unpad.ac.id) data base. 
Guyton \& Hall. (2008). Fisiologi Kedokteran.

Edisi 11. Jakarta: Penerbit Buku Kedokteran EGC.

Hastono, S.P. (2007). Analisis Data Kesehatan. Jakarta: Fakultas Kesehatan Masyarakat Universitas Indonesia.

Kaushik, et al. (2006). Effects of Mental Relaxation and Slow Breathing in Essentihypertension. Complementary Therapies in Medecine. Vol 14(2). Pp. 120-126.

Kozier dan ERB'SI. (2011). Fundamental of Nursing: Concepts, Process and Practice, Ed. 9. Edit Vol 2. Berman \& Syder,S. New York: Pearson.

Kemenkes. (2013). Riset Kesehatan Dasar Badan Penelitian dan Pengembangan Leodin, dkk. (2003). Pedoman Nasional Etik Penelitian Kesehatan. Rapat Kerja I Komisi Nasional Etik Penelitian Kesehatan. Jakarta.
Kusyanti, Eni. (2003). Keterampilan dan Prosedur Keperawatan Dasar. Jakarta: EGC.

Kwekkeboon, et al. (2008). Patients' Perceptions of the Effectiveness of Guided Imagery and Progressive Muscle Relaxation Interventions Used for Cancer Pain. Complementary theraphies in clinical practice. Vol 14(3). 185.194.

Leodin, dkk. (2003). Pedoman Nasional Etik Penelitian Kesehatan. Rapat Kerja I Komisi Nasional Etik Peneitian Kesehatan. Jakarta.

Lindquist, R, Snyder, M \& Tracy, MF. (2013). Complementary \& Alternative Therapies in Nursing: Seventh Edition. New York: Springer Publising Company.

Miltenberger, R. G. (2004). Behavior Modification, Principles and Procedures, 3th. 